\title{
Impact of Social Media on Academic Performance
}

\author{
Manahil Jamil, Qurat ul Ain, Salma Batool, Sidra Saadat, Shaista Malik, Moniba Arshad, Ramisha \\ Naseer Nagra, Maryam Haider, Rabia Shameem and Bushra Latif
}

\section{ABSTRACT}

Social media is a mode of communication, influencing nearly every field of life. Researchers have found that the use of social media can be addictive, which may cause significant impairment in various aspects of an individual's life. This study has been designed to investigate the impact of Social Networking on students' academic performance in Islamabad and Rawalpindi (Pakistan). This Cross-sectional study was conducted from April 2019 to February 2020. 385 students of age 15 to 25 years, enrolled in different educational institutes of twin cities were included in the study. Data was collected using self-designed Questionnaire. Analysis of data was performed using SPSS V.21. Total of 348 participants were included from different educational institutes of Rawalpindi and Islamabad city. Studies show that among youth, teen age group was more addicted to social networking and maximum participants were using social media for more than 3 years for just recreation or relaxation purpose. Though the results do not show statistical significance (Social Network Usage per 24 hours* Negative Effect of social networking on study timings p-value 0.061) but being close to the statistically significant figure, shows that somehow the fact that spending more time on social network has overall negative effect on academic's outcome. We cross tabulated, duration since using social network with social network usage/24 hours and found statistically significant association between it (i.e. $p$ - value $=0.000$ ) which shows that those who were using social media for longer duration are actually using it for no specific reason or fruitful purpose. Most of the subjects under study were females in both age groups. More time spent on social media in $\mathbf{2 4}$ hours affects the study timings negatively thus affecting the study outcome and academic results.

Keywords: Social Media, Academic Performance.

\section{INTRODUCTION}

Social media defined as producing, sharing, and collaborating content online. It includes a variety of applications such as social networking sites, virtual game and social worlds [1].

Social media is a means of communication which allows people to connect. It has influenced nearly every field of life as political, social, economic, and educational. Social media use been rapidly increasing during the last few years and is
Published Online: October 30, 2020

ISSN: $2593-8339$

DOI: $10.24018 /$ ejmed.2020.2.5.512

Manahil Jamil*

Rawalpindi Medical University,

Rawalpindi, Pakistan.

(e-mail: manahil.jamil97@ gmail.com)

Qurat ul Ain

Rawalpindi Medical University,

Rawalpindi, Pakistan.

Salma Batool

Rawalpindi Medical University, Rawalpindi, Pakistan.

Sidra Saadat

Rawalpindi Medical University, Rawalpindi, Pakistan.

Shaista Malik

Rawalpindi Medical University, Rawalpindi, Pakistan.

\section{Moniba Arshad}

Rawalpindi Medical University, Rawalpindi, Pakistan.

Ramisha Naseer Nagra Rawalpindi Medical University, Rawalpindi, Pakistan.

\section{Maryam Haider}

Rawalpindi Medical University, Rawalpindi, Pakistan.

\section{Rabia Shameem}

Rawalpindi Medical University, Rawalpindi, Pakistan.

Bushra Latif

Rawalpindi Medical University, Rawalpindi, Pakistan.

*Corresponding Author being used by people all over the world especially the students [2]. Social media plays a central role in learning environments as a crucial communication network. Social media has many advantages in the educational field; it provides access to information, supports learning attitudes, provides social support, encourages self-learning and allows collective learning [3]. As Social networking use is becoming increasingly common; many concerns are being raised. Researchers have found that the use of Social media can be addictive, which may cause significant impairment in 
various aspects of an individual's life [4], [5]. This SNS addiction is social media overuse which in the current study is taken as more than 2 hours of daily social media use.

Many studies have suggested a detrimental effect of social media on academic performance relating it to decreasing learning abilities, dropping homework completion, and worsening academic achievements [6]-[8]. It harms study timings resulting in a decrease in the daily amount of productive study time, causing a disadvantageous effect on student's academic performance. Johnson et al. have associated frequent SNS use with elevated risk for attention and learning difficulties [6]. Excessive visual media has resulted in substance abuse, problematic behavior, and risk-taking attitude, which also impair school performance [9]. The purpose of the current study is to investigate the impact of Social Networking (Facebook, WhatsApp, Instagram, Google, YouTube, Twitter, LinkedIn) on students' academic performance in Pakistan.

\section{MATERIALS AND METHODS}

This descriptive, cross-sectional study was conducted from April 2019 to February 2020; in which 385 youth of age 15 to 25 years enrolled in different educational institutes of twin cities that is Rawalpindi and Islamabad, Pakistan, were included in the study population. Students either don't have an android phone or don't have internet access were excluded from the study. Data were collected using a selfdesigned structured questionnaire distributed to students with a response rate of $100 \%$. A descriptive analysis of the study variables was performed using SPSS v.21.0. ChiSquare Test was employed, and a p-value $<0.05$ was considered statistically significant.

\section{RESULTS}

The study was conducted in twin cities that are Rawalpindi and Islamabad of the Islamic Republic of Pakistan. In this study total of 348 participants were included from different educational institutes of the mentioned study setting. Studies show that among youth, the teenage group was more addicted to social media, and maximum participants were using social media for more than three years for just recreation or relaxation purpose. Statistics regarding demographics and general social media usage has been given in Table I and II and Fig. 1a, 1b.

TABLE I: DEMOGRAPHICS AND USE OF SOCIAL MEDIA

\begin{tabular}{c|ccccc}
\hline \multicolumn{2}{c}{ Age } & $\begin{array}{c}\text { Level of } \\
\text { Education }\end{array}$ & $\begin{array}{c}\text { Duration of } \\
\text { Social } \\
\text { media usage }\end{array}$ & $\begin{array}{c}\text { Social } \\
\text { media } \\
\text { usage per } \\
24 \text { hours }\end{array}$ & $\begin{array}{c}\text { Purpose of } \\
\text { using Social } \\
\text { Media }\end{array}$ \\
\hline Mode & $\begin{array}{c}16-20 \\
\text { years }\end{array}$ & $\begin{array}{c}\text { Undergra } \\
\text { duate }\end{array}$ & $>3$ years & $2-4$ hours & $\begin{array}{c}\text { As a source } \\
\text { of recreation } \\
\text { and } \\
\text { relaxation }\end{array}$ \\
$\begin{array}{c}\text { STD. } \\
\text { Deviat } \\
\text { ion }\end{array}$ & 0.517 & 0.537 & 0.964 & 0.974 & 0.999 \\
\hline
\end{tabular}


use and social network usage/24 hours, respectively with the negative effect of social networking on study timings and impact of social networking on academic performance and found some interesting associations. Results being not statistically significant (duration of social network usage*impact on studies p-value 0.269 ; duration of social network usage*negative effect on study timings p-value
0.105; social network usage per 24 hours*impact on studies p-value 0.985 ; social network. usage per 24 hours* negative effect on study timings p-value 0.061) shows that neither duration of social network usage nor social network usage per 24 hours has any association with impact or negative effects on academic performance (Table IIIa, IIIb, IIIc and IIId).

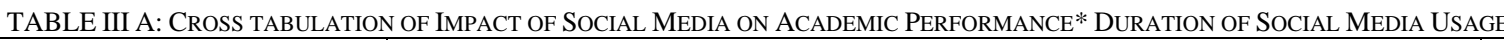

\begin{tabular}{|c|c|c|c|c|c|c|}
\hline & & \multicolumn{4}{|c|}{ Duration of Social Media Usage } & \multirow{2}{*}{ Total } \\
\hline & & Less than 6 months & 6 months - 1 year & 1 year -3 years & more than 3 years & \\
\hline $\begin{array}{c}\text { Impact of Social Media on } \\
\text { Academic Performance }\end{array}$ & Negative & 19 & 22 & 57 & 149 & 247 \\
\hline \multicolumn{2}{|l|}{ Total } & 29 & 35 & 72 & 212 & 348 \\
\hline
\end{tabular}

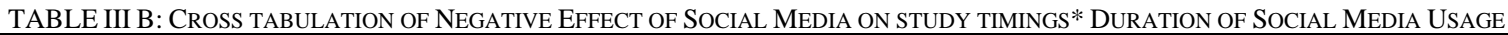

\begin{tabular}{|c|c|c|c|c|c|c|}
\hline & & \multicolumn{4}{|c|}{ Duration of Social Media Usage } & \multirow{2}{*}{ Total } \\
\hline & & Less than 6 months & 6 months - 1 year & 1 year -3 years & more than 3 years & \\
\hline \multirow{2}{*}{$\begin{array}{l}\text { Negative Effect of social media } \\
\text { on study timings }\end{array}$} & Agree & 23 & 22 & 60 & 168 & 273 \\
\hline & Disagree & 6 & 13 & 12 & 44 & 75 \\
\hline
\end{tabular}

TABLE III C: CROSS TABULATION OF IMPACT OF SOCIAL MEDIA ON ACADEMIC PERFORMANCE* SOCIAL MEDIA USAGE PER 24 HOURS

\begin{tabular}{|c|c|c|c|c|c|c|}
\hline & & \multicolumn{4}{|c|}{ Social Media Usage per 24 hours } & \multirow{2}{*}{ Total } \\
\hline & & Less than 2 hours & $2-4$ hours & $5-7$ hours & more than 7 hours & \\
\hline \multirow{2}{*}{ Impact of Social Media on Studies } & Positive & 29 & 37 & 23 & 12 & 101 \\
\hline & Negative & 69 & 89 & 61 & 28 & 247 \\
\hline \multicolumn{2}{|l|}{ Total } & 98 & 126 & 84 & 40 & 348 \\
\hline
\end{tabular}

TABLE III D: CROSS TABULATION OF NEGATIVE EFFECT OF SOCIAL MEDIA NETWORKING ON STUDY TIMINGS* SOCIAL MEDIA USAGE PER 24 HOURS

\begin{tabular}{|c|c|c|c|c|c|c|}
\hline & & \multicolumn{4}{|c|}{ Social Media Usage per 24 hours } & \multirow[b]{2}{*}{ Total } \\
\hline & & $\begin{array}{c}\text { Less than } 2 \\
\text { hours }\end{array}$ & $2-4$ hours & $5-7$ hours & more than 7 hours & \\
\hline \multirow{2}{*}{$\begin{array}{l}\text { Negative Effect of social media } \\
\text { networking on study timings }\end{array}$} & Agree & 69 & 102 & 66 & 36 & 273 \\
\hline & Disagree & 29 & 24 & 18 & 4 & 75 \\
\hline \multicolumn{2}{|l|}{ Total } & 98 & 126 & 84 & 40 & 348 \\
\hline
\end{tabular}

Though the results do not show statistical significance but being close to the statistically significant figure, shows that somehow the fact that spending more time on social media has an overall negative effect on the academic outcome.

We did cross-tabulate the purpose of using social media with the duration since using social media and social media usage/24 hours. We found a statistically significant association between duration since usage and purpose ( $p$ value $=0.000$ ) which shows that those who were using social media for longer duration are using it for no specific reason or fruitful purpose, they take social media as a source of time pass and recreation (Table IV).

\section{DISCUSSION}

Social Media services are being used in various capacities for social, commercial and educational purposes. They not only enable communication but also offer possibilities to share user-generated content such as photos and videos and have features such as social games.

In the current study, we collected data from 348 students, all of whom were using Social media. The study included not only undergraduate students but also postgraduates, secondary school, and higher secondary school students, making it broad-based. This study confirmed that social networking sites are a prominent mode of communication among students, especially teenagers and this result is consistent with other studies showing that teenagers are among the most prolific users of social media [10], [11]. 
Youth spends a significant portion of their daily life on social media. In the current study, among 348 students, $36.2 \%$ reported the use of Social Media for 2-4 hours which is in line with the previous study results showing that most students use social media daily for more than 2 hours [10]. Another study by El-Badawy TA and Hashem Y also reported similar results showing a majority of students spending 1-3 hours on Social media [12]. This excessive use is because students are accessing the internet through smartphones which have become quite affordable now. Additionally, given that the majority of students $(60.9 \%)$ have been using social media for more than three years, Social Networking services have embedded themselves in the daily lives of students this is more than the time reported in an Indian study conducted in 2012 [13].

TABLE IV: CROSS TABULATION OF PURPOSE OF USING SOCIAL MEDIA* DURATION OF USING SOCIAL MEDIA

\begin{tabular}{|c|c|c|c|c|c|c|}
\hline & & \multicolumn{5}{|c|}{ Duration of Social Media Usage } \\
\hline & & $<6$ months & $\begin{array}{c}6 \text { months }-1 \\
\text { year }\end{array}$ & $\begin{array}{l}1 \text { year- } 3 \\
\text { years }\end{array}$ & $>3$ years & Total \\
\hline \multirow{5}{*}{$\begin{array}{l}\text { Purpose of using } \\
\text { Social media }\end{array}$} & Socialize \& make new friends & 9 & 3 & 4 & 9 & 25 \\
\hline & Remain updated about trends & 2 & 7 & 20 & 77 & 106 \\
\hline & $\begin{array}{c}\text { Collaborate with fellow } \\
\text { students \& study }\end{array}$ & 7 & 12 & 21 & 36 & 76 \\
\hline & $\begin{array}{c}\text { As a source of recreation \& } \\
\text { relaxation }\end{array}$ & 11 & 13 & 27 & 90 & 141 \\
\hline & Total & 29 & 35 & 72 & 212 & 348 \\
\hline
\end{tabular}

According to the current study, $40.5 \%$ of students use social media as a source of recreation and relaxation whereas $21.8 \%$ of students use it for educational purposes which are less than the number in the study conducted by Waqas et al. and almost equal to study by Guraya SY [10], [14]. Nearly $90 \%$ of our respondents suggested that social media can help in academics and research. It is an encouraging finding as social media usage for academics at this stage means that these students are already knowledgeable about utilizing social media to exchange information and perform research. Another Pakistani study has reported comparable responses from students showing that Social media plays positive roles in academic activities [15]. In a recent study conducted among medical students in East India, the responders believe that proper use of Social media can positively impact academic performance [4]. Selwyn has commented that the use of SNS in education can be described by the fact that due to the advent of useroriented learning, institutional learning has come to a standstill [16]. While $90 \%$ of students suggested that social media can be helpful in academics, $78 \%$ of the responders believe that purposeless use of social media has decreased the productive study time affecting academic performance. In studies conducted on students in Pakistan, excessive purposeless Social Networking results in poor academic performance [10], [17]. These results are consistent with studies conducted in Iran and West Bengal India showing similar results [3], [18]. However, El-Badawy and Hashem reported no significant relationship or difference between both the frequency of using social media with academic performance [12].

It can be said that excessive use of social media negatively affects the students' academic performance which is because excessive use of social media is associated with stress which further affects academic performance [19]. Uninhibited use of social media reduces study time, which has negatively affected the academic performance of students. People who spend much of their time on social media do not have enough rest resulting in poor sleep and fatigue, which further results in decreased concentration and poor learning capabilities [20]. Further evidence indicates a substantial relation between the inappropriate use of technology and academic problems [21], [22].

Social media is not destructive, but rather the way it's used, determine positive and negative consequences. The current research has shown a significant association between the duration of usage and the purpose of using Social media, showing purposeless long-term use of Social media ( $p$ value $=0.000$ ). We could not find this correlation in any of the previous researches conducted locally as well as internationally. Social media is becoming increasingly enticing; students should keep in mind to use it appropriately and thoughtfully because it is possible to get addicted to it.

Overall, our data indicated that long term and purposeless use of Social media is detrimental to academic performance, but its appropriate use can benefit the students in academics as well as research. However, the current study has some limitations which include its cross-sectional design, which impedes establishing the causal direction of the observed associations, and the use of self-reported questionnaires.

Strengths of the study are that data were collected from different institutes and also from each level of education that is schools, colleges and universities.

\section{CONCLUSION}

Most of the subjects under study were females in both age groups. More time spent on social networking sites per 24 hours affects the study timings in a negative sense, thus affecting the study outcome and academic results.

\section{CONFLICTS OF INTEREST}

In compliance with the ICJME uniform disclosure form, all authors declare the following: 
A. Payment/services info: All authors have declared that no financial support was received from any organization for the submitted work.

B. Financial relationships: All authors have declared that they need no financial relationships at the present or within the previous three years with any organizations which may have an interest within the submitted work.

C. Other relationships: All authors have declared that there are not any other relationships or activities that would appear to possess influenced the submitted work.

\section{REFERENCES}

[1] Kuss DJ, Griffiths MD. Social networking sites and addiction: Ten lessons learned [Internet]. Vol. 14, International Journal of Environmental Research and Public Health. MDPI AG; 2017 [cited 2020 Oct 4]. Available from: /pmc/articles/PMC5369147/?report=abstract

[2] Raut Prafulla Patil V. Use of Social Media in Education: Positive and Negative impact on the students. Int J Recent Innov Trends Comput Commun. 2016;4(1):281-5.

[3] Azizi SM, Soroush A, Khatony A. The relationship between social networking addiction and academic performance in Iranian students of medical sciences: A cross-sectional study. BMC Psychol. 2019 May;7(1).

[4] Lahiry S, Choudhury S, Chatterjee S, Hazra A. Impact of social media on academic performance and interpersonal relation: A crosssectional study among students at a tertiary medical center in East India. J Educ Health Promot. 2019;8:73.

[5] Problematic social media use - Wikipedia.

[6] Johnson JG, Cohen P, Kasen S, Brook JS. Extensive television viewing and the development of attention and learning difficulties during adolescence. Arch Pediatr Adolesc Med. 2007 May;161(5):480-6.

[7] Wiecha JL, Sobol AM, Peterson KE, Gortmaker SL. Household television access: associations with screen time, reading, and homework among youth. Ambul Pediatr. 2001;1(5):244-51.

[8] Sharif I, Sargent JD. Association Between Television, Movie, and Video Game Exposure and School Performance. Pediatrics. 2006 Oct;118(4):e1061-70.

[9] Sharif I, Wills TA, Sargent JD. Effect of visual media use on school performance: a prospective study. J Adolesc Health [Internet]. 2009/07/03. 2010 Jan;46(1):52-61. Available from https://www.ncbi.nlm.nih.gov/pubmed/20123258

[10] Waqas A, Afzal M, Zaman F, Sabir M. The Impact of Social Networking Sites' Usage on the Academic Performance of University Students of Lahore, Pakistan. Int J Soc Sci Manag. 2016 Oct;3(4):267-76.

[11] Ahn J. The effect of social network sites on adolescents' social and academic development: Current theories and controversies. J Am Soc Inf Sci Technol. 2011 Aug;62(8):1435-45.

[12] El-Badawy TA, Hashem Y. The Impact of Social Media on the Academic Development of School Students. Int J Bus Adm. 2014 Dec;6(1).

[13] Meena P, Mittal P, Solanki R. Problematic use of social networking sites among urban school going teenagers. Ind Psychiatry J. 2012;21(2):94.

[14] Guraya SY. The usage of social networking sites by medical students for educational purposes: A meta-analysis and systematic review. Vol. 8, North American Journal of Medical Sciences. North American Journal of Medical Sciences; 2016. p. 268-78.

[15] Khalid H. The Effects of Social Networks on Pakistani Students. J Inf Technol Softw Eng. 2017;7(3).

[16] Selwyn N. Looking beyond learning: notes towards the critical study of educational technology. J Comput Assist Learn. 2010 Jan;26(1):65-73

[17] Javaeed A, Jeelani R, Gulab S, Ghauri SK. Relationship between internet addiction and academic performance of undergraduate medical students of Azad Kashmir. Pakistan J Med Sci. 2020 Jan;36(2):229-33.

[18] Raj M, Bhattacherjee S, Mukherjee A. Usage of online social networking sites among school students of Siliguri, West Bengal, India. Indian J Psychol Med. 2018 Sep;40(5):452-7.
[19] Gabre HG, Kumar G. The Effects of Perceived Stress and Facebook on Accounting Students' Academic Performance. Account Financ Res. 2012;1(2).

[20] Bijari B, Javadinia SA, Erfanian M, Abedini M, Abassi A. The Impact of Virtual Social Networks on Students' Academic Achievement in Birjand University of Medical Sciences in East Iran Procedia - Soc Behav Sci. 2013 Jul;83:103-6.

[21] Kubey RW, Lavin MJ, Barrows JR. Internet Use and Collegiate Academic Performance Decrements: Early Findings. J Commun. 2001 Jun;51(2):366-82.

[22] Malaney GD. Student Use of the Internet. J Educ Technol Syst. 2004 Sep;33(1):53-66

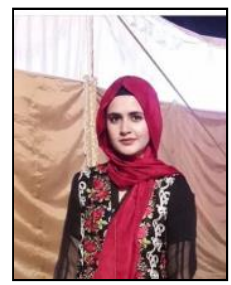

Manahil Jamil

Place of birth: Vehari, Pakistan.

Date of birth: 30 ${ }^{\text {th }}$ January, 1997

Educational Background: Final year MBBS student, Rawalpindi Medical University, Rawalpindi, Pakistan

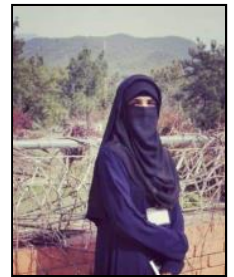

\section{Qurat ul Ain}

Place of birth: Rawalpindi, Pakistan

Date of birth: $28^{\text {th }}$ February, 1995

Educational Background: Final year MBBS student, Rawalpindi Medical University, Rawalpindi, Pakistan 